\title{
REFORMULASI PENGALOKASIAN DANA DESA TAHUN ANGGARAN 2020
}

\author{
Fitria Zana Kumala \\ Institut Agama Islam Negeri Purwokerto \\ fitriazana@iainpurwokerto.ac.id
}

\begin{abstract}
This study aims to determine the difference between the allocation of Village Fund in the fiscal year of 2019 and 2020 and also describe the factors that cause the changes in the formula for allocating Village Fund in the fiscal year of 2020. This research uses descriptive qualitative method where the data of allocating Village Fund in the fiscal year of 2019 and 2020 are used based on the Regulation of the Minister of Finance of the Republic of Indonesia concerning Management of Village Fund. Unstructured interview with Participatory Development Expert of Purbalingga Regency was conducted to find out the factors that cause the changes in the formula for allocating Village Fund in the fiscal year of 2020. From this study it can be concluded that the difference between the allocation of Village Fund in the fiscal year of 2019 and 2020 is on the formula used for the allocation of Village Fund where in the fiscal year of 2019, the allocation of Village Fund for each village and district/ city is allocated based on only three types of allocations, namely Basic Allocation, Affirmation Allocation, and Formula Allocation while in the fiscal year of 2020, the allocation is based on four types of allocation, namely Basic Allocation, Affirmation Allocation, Performance Allocation, and Formula Allocation. The difference is also on the percentage of funding ceiling for each allocation. In the fiscal year of 2019 the Basic Allocation funding ceiling is 72\% of the national budget for $V$ illage Fund then drop to 69\% of the national budget for Village Fund in the fiscal year of 2020. In the fiscal year of 2019 the Affirmative Allocation funding ceiling is 3\% of the national budget for Village Fund then drop to 1.5\% of the national budget for Village Fund in the fiscal year of 2020. In the fiscal year of 2019 there is no Performance Allocation funding ceiling, while in the fiscal year of 2020 there is a Performance Allocation which is $1.5 \%$ of the national budget for Village Fund. In the fiscal year of 2019 the Formula Allocation funding ceiling is 25\% of the national budget for Village Fund then rises to $28 \%$ of the national budget for Village Fund in the fiscal year of 2020. Furthermore, the factors that cause the changes in the Village Fund allocation formula in the fiscal year of 2020, found that villages do not want an increase in the status of the village because it will lose their Affirmation Allocation, evaluation from the government to reduce the percentage of Basic Allocation to give better reflect the fairness and condition of the village, evaluation from the government to increase the Allocation Formula to give better reflect to the real conditions of the village based on population, poor population, size region and geographical difficulty index, as well as granting appreciation / reward from the government in the form of granting Performance Allocation to villages that have the best performance.
\end{abstract}

Keywords: Village Funds; Reformulation of Village Fund Allocation 


\section{Abstrak}

Penelitian ini bertujuan untuk mengetahui perbedaan pengalokasian Dana Desa (DD) tahun anggaran 2019 dan 2020 serta mendeskripsikan faktor-faktor yang menyebabkan perubahan formula pengalokasian Dana Desa pada tahun anggaran 2020. Metode penelitian ini menggunakan metode deskriptif kualitatif dimana data mengenai pengalokasian Dana Desa pada tahun anggaran 2019 dan 2020 yang digunakan adalah berdasarkan Peraturan Menteri Keuangan Republik Indonesia tentang Pengelolaan Dana Desa. Wawancara tidak terstruktur dengan Tenaga Ahli Pembangunan Partisipatif Kabupaten Purbalingga dilakukan untuk mengetahui faktor-faktor yang menyebabkan perubahan formula pengalokasian Dana Desa pada tahun anggaran 2020. Dari penelitian ini dapat disimpulkan bahwa perbedaan pengalokasian Dana Desa pada tahun anggaran 2019 dan 2020 terletak pada perubahan formula yang digunakan untuk pengalokasian Dana Desa dimana pada tahun anggaran 2019 rincian Dana Desa setiap desa dan daerah kabupaten/ kota dialokasikan berdasarkan tiga jenis alokasi saja, yaitu Alokasi Dasar, Alokasi Afirmasi, dan Alokasi Formula sedangkan pada tahun anggaran 2020 pengalokasian tersebut berdasarkan empat jenis alokasi, yaitu Alokasi Dasar, Alokasi Afirmasi, Alokasi Kinerja, dan Alokasi Formula. Perbedaan juga terletak pada persentase pagu setiap alokasi. Pada tahun anggaran 2019 pagu Alokasi Dasar adalah sebesar 72\% dari anggaran Dana Desa nasional kemudian turun menjadi 69\% dari anggaran Dana Desa nasional pada tahun anggaran 2020. Pada tahun anggaran 2019 pagu Alokasi Afirmasi adalah sebesar 3\% dari anggaran Dana Desa nasional kemudian turun menjadi 1.5\% dari anggaran Dana Desa nasional pada tahun anggaran 2020. Pada tahun anggaran 2019 tidak terdapat pagu Alokasi Kinerja, sedangkan pada tahun anggaran 2020 terdapat Alokasi Kinerja yang besarnya 1.5\% dari anggaran Dana Desa nasional. Pada tahun anggaran 2019 pagu Alokasi Formula adalah sebesar 25\% dari anggaran Dana Desa nasional kemudian naik menjadi 28\% dari anggaran Dana Desa nasional pada tahun anggaran 2020. Selanjutnya faktorfaktor yang menyebabkan perubahan formula pengalokasian Dana Desa pada tahun anggaran 2020 adalah terdapat desa yang tidak menginginkan kenaikan status desa karena akan kehilangan Alokasi Afirmasi, evaluasi dari pemerintah untuk menurunkan persentase Alokasi Dasar agar lebih mencerminkan keadilan dan kondisi desa, evaluasi dari pemerintah untuk menaikkan Alokasi Formula agar lebih mencerminkan kondisi riil desa berdasarkan jumlah penduduk, jumlah penduduk miskin, luas wilayah, dan indeks kesulitan geografis, serta pemberian apresiasi/ reward dari pemerintah berupa pemberian Alokasi Kinerja kepada desa-desa yang memiliki kinerja terbaik.

Kata kunci: Dana Desa; Reformulasi Pengalokasian Dana Desa 


\section{Pendahuluan}

Undang-Undang Nomor 6 Tahun 2014 tentang Desa telah menempatkan desa sebagai ujung tombak pembangunan dan peningkatan kesejahteraan masyarakat. Undang-Undang tersebut juga digunakan sebagai dasar yang digunakan Pemerintah Desa dalam menjalankan urusan masing-masing Pemerintah Desa. Desa diberikan kewenangan dan sumber dana yang jumlahnya memadai dimana dana tersebut dibagikan ke seluruh desa di Indonesia setiap tahun agar desa dapat mengelola potensi yang dimilikinya guna meningkatkan ekonomi dan kesejahteraan masyarakat. Dana tersebut disebut sebagai Dana Desa (DD).

Dalam Undang-Undang Nomor 6 Tahun 2014 disebutkan bahwa Dana Desa adalah dana yang bersumber dari Anggaran Pendapatan dan Belanja Negara yang diperuntukkan bagi Desa yang ditransfer melalui Anggaran Pendapatan dan Belanja Daerah Kabupaten/Kota dan digunakan untuk mendanai penyelenggaraan pemerintah, pelaksanaan pembangunan, pembinaan kemasyarakatan, dan pemberdayaan masyarakat. Selanjutnya, dalam UndangUndang tersebut disebutkan juga bahwa tujuan Dana Desa adalah untuk meningkatkan pelayanan publik di desa, mengentaskan kemiskinan, memajukan perekonomian desa, mengatasi kesenjangan pembangunan antar desa, dan memperkuat masyarakat desa sebagai subjek dari pembangunan.

Dalam Peraturan Menteri Keuangan Republik Indonesia Nomor 40/PMK.07/2020 tentang Pengelolaan Dana Desa disebutkan bahwa pengelolaan Dana Desa tersebut meliputi: penganggaran; pengalokasian; penyaluran; penatausahaan, pertanggungjawaban, dan pelaporan; pedoman penggunaan; dan pemantauan serta evaluasi.

Dalam pengalokasian Dana Desa, pemerintah melalui Kementerian Keuangan membuat formula yang digunakan untuk menghitung alokasi Dana Desa yang diterima setiap desa di seluruh wilayah Indonesia. Formula untuk menghitung alokasi Dana Desa tersebut pada tahun anggaran 2020 mengalami perubahan dibandingkan dengan formula yang digunakan untuk menghitung alokasi Dana Desa pada tahun anggaran 2019. Perubahan tersebut dilakukan berdasarkan hasil evaluasi Kementerian Keuangan bersama dengan Kementerian Dalam Negeri dan Kementerian Desa, Pembangunan Daerah Tertinggal dan Transmigrasi Republik Indonesia terhadap formula yang digunakan untuk menghitung alokasi Dana Desa pada tahun anggaran 2019.

Penelitian ini bertujuan untuk mengetahui perbedaan pengalokasian Dana Desa (DD) tahun anggaran 2019 dan 2020 serta mendeskripsikan faktor-faktor yang menyebabkan perubahan formula pengalokasian Dana Desa pada tahun anggaran 2020. Dengan dilakukannya penelitian ini maka akan dapat diketahui perbedaan pengalokasian Dana Desa (DD) tahun anggaran 2019 dan 2020 serta faktor-faktor apa saja yang menyebabkan perubahan formula pengalokasian Dana Desa pada tahun anggaran 2020. 


\section{Kajian Teori}

\section{A. Pengertian Dana Desa}

Dana Desa (DD) adalah dana yang bersumber dari Anggaran Pendapatan dan Belanja Negara yang diperuntukkan bagi Desa yang ditransfer melalui Anggaran Pendapatan dan Belanja Daerah Kabupaten/Kota dan digunakan untuk mendanai penyelenggaraan pemerintah, pelaksanaan pembangunan, pembinaan kemasyarakatan, dan pemberdayaan masyarakat. ${ }^{1}$

\section{B. Tujuan Dana Desa}

Berdasarkan Undang-Undang Nomor 6 Tahun 2014 tentang Desa, diketahui bahwa tujuan pemberian Dana Desa adalah untuk meningkatkan pelayanan publik di desa, mengentaskan kemiskinan, memajukan perekonomian desa, mengatasi kesenjangan pembangunan antar desa, dan memperkuat masyarakat desa sebagai subjek dari pembangunan.

\section{Konsep Evaluasi}

Wirawan (2006) dalam Aljannah (2017:816) menjelaskan bahwa evaluasi adalah proses pengumpulan dan menyajikan informasi mengenai objek evaluasi, menilainya dengan standar evaluasi dan evaluasinya dipergunakan untuk mengambil keputusan mengenai objek evaluasi.

Pemerintah telah melakukan evaluasi terhadap formula yang digunakan untuk menghitung alokasi Dana Desa pada tahun anggaran 2019. Hasil dari evaluasi tersebut menyebabkan adanya perubahan formula yang digunakan untuk menghitung alokasi Dana Desa pada tahun anggaran 2020.

\section{Metode Penelitian}

Metode yang digunakan dalam penelitian ini adalah metode deskriptif kualitatif dimana data mengenai pengalokasian Dana Desa pada tahun anggaran 2019 dan 2020 yang digunakan adalah berdasarkan Peraturan Menteri Keuangan Republik Indonesia Nomor 193/PMK.07/2018 tentang Pengelolaan Dana Desa, Peraturan Menteri Keuangan Republik Indonesia Nomor 205/PMK.07/2019 tentang Pengelolaan Dana Desa dan Peraturan Menteri Keuangan Republik Indonesia Nomor 40/PMK.07/2020 tentang Perubahan atas Peraturan Menteri Keuangan Nomor 205/PMK.07/2019 tentang Pengelolaan Dana Desa. Faktor-faktor yang menyebabkan perubahan formula pengalokasian Dana Desa pada tahun anggaran 2020 diketahui melalui wawancara tidak terstruktur dengan Tenaga Ahli Pembangunan Partisipatif Kabupaten Purbalingga.

${ }_{1}$ Peraturan Menteri Keuangan Republik Indonesia Nomor 40/PMK.07/2020 tentang Pengelolaan Dana Desa, pasal 1. 


\section{Hasil dan Pembahasan}

\section{A. Pengalokasian Dana Desa Tahun Anggaran 2019}

Pengalokasian Dana Desa Tahun Anggaran 2019 dibagi menjadi dua bagian pembahasan, yaitu pengalokasian Dana Desa setiap daerah kabupaten/ kota tahun anggaran 2019 dan pengalokasian Dana Desa setiap desa di daerah kabupaten/ kota tahun anggaran 2019 sebagai berikut:

\section{Pengalokasian Dana Desa setiap Daerah Kabupaten /Kota Tahun Anggaran 2019}

Besaran Dana Desa setiap daerah kabupaten/ kota tahun anggaran 2019 dialokasikan secara merata dan berkeadilan berdasarkan tiga jenis alokasi, yaitu Alokasi Dasar, Alokasi Afirmasi, dan Alokasi Formula. Pagu Alokasi Dasar besarnya adalah 72\% dari anggaran Dana Desa yang dibagi sama rata kepada setiap desa. Pagu Alokasi Afirmasi besarnya adalah 3\% dari anggaran Dana Desa yang dibagi secara proporsional kepada Desa Tertinggal (DT) dan Desa Sangat Tertinggal (DST) yang memiliki jumlah penduduk miskin tinggi, yaitu Desa Tertinggal dan Desa Sangat Tertinggal yang memiliki jumlah penduduk miskin terbanyak yang berada pada desil ke delapan, sembilan, dan sepuluh berdasarkan perhitungan dari Direktorat Jenderal Perimbangan Keuangan. Status Desa Tertinggal dan Desa Sangat Tertinggal tersebut ditetapkan berdasarkan data Indeks Desa Membangun (IDM) yang diterbitkan oleh Kementerian Desa, Pembangunan Daerah Tertinggal, dan Transmigrasi Republik Indonesia, dan data jumlah penduduk miskin yang digunakan adalah data dari Badan Pusat Statistik (BPS) atau Kementerian Sosial Republik Indonesia. ${ }^{2}$

Selanjutnya, Pagu Alokasi Formula besarnya adalah 25\% dari anggaran Dana Desa yang dibagi kepada desa berdasarkan bobot yang berbeda, yaitu 10\% untuk jumlah penduduk desa, 50\% untuk angka kemiskinan desa, 15\% untuk luas wilayah desa, dan $25 \%$ untuk tingkat kesulitan geografis desa. ${ }^{3}$ Angka kemiskinan desa dilihat dari jumlah penduduk miskin desa, sedangkan tingkat kesulitan geografis desa dilihat dari Indeks Kemahalan Konstruksi (IKK) daerah kabupaten/ kota. ${ }^{4}$ IKK adalah indeks yang mencerminkan tingkat kesulitan geografis yang dinilai berdasarkan tingkat kemahalan harga prasarana fisik secara relatif antar daerah. ${ }^{5}$ Data jumlah penduduk desa, angka kemiskinan desa, luas wilayah desa, dan IKK daerah kabupaten/ kota tersebut diperoleh dari Kementerian Dalam Negeri Republik Indonesia, Kementerian Sosial Republik Indonesia, dan/atau Badan Pusat Statistik (BPS). Jika data tersebut tidak tersedia, maka dapat digunakan data dari data

\footnotetext{
2 Peraturan Menteri Keuangan Republik Indonesia Nomor 193/PMK.07/2018 tentang Pengelolaan Dana Desa, pasal 5.

3 Ibid.

${ }^{4}$ Ibid., Pasal 5.

5 lbid., Pasal 1.
} 
desa induk secara proporsional atau data yang bersumber dari Pemerintah Daerah. ${ }^{6}$

Dana Desa setiap daerah kabupaten/ kota tahun anggaran 2019 dihitung dengan menggunakan formula sebagai berikut: ${ }^{7}$

DD Kab/ Kota 2019= AD Kab/ Kota 2019 + AA Kab/ Kota $2019+$ AF

$$
\mathrm{Kab} / \text { Kota } 2019
$$

dimana:

DD Kab/ Kota 2019: Dana Desa setiap Daerah kabupaten/ kota tahun anggaran 2019

AD Kab/ Kota 2019: Alokasi Dasar setiap Daerah kabupaten/ kota tahun anggaran 2019

AA Kab/ Kota 2019: Alokasi Afirmasi setiap Daerah kabupaten/ kota tahun anggaran 2019

AF Kab/ Kota 2019 : Alokasi Formula setiap Daerah kabupaten/ kota tahun anggaran 2019

\section{a. Alokasi Dasar setiap Daerah Kabupaten/ Kota Tahun Anggaran 2019}

Alokasi Dasar setiap daerah kabupaten/ kota tahun anggaran 2019 dihitung dengan menggunakan formula sebagai berikut: ${ }^{8}$

AD Kab/ Kota $2019=$ AD Desa 2019 x D Kab/ Kota dimana:

AD Kab/ Kota 2019:Alokasi Dasar setiap daerah kabupaten/ kota tahun anggaran 2019

AD Desa 2019 :Alokasi Dasar setiap desa di daerah kabupaten/ kota tahun anggaran 2019

D Kab/ Kota : :jumlah desa di daerah kabupaten/ kota

Selanjutnya, Alokasi Dasar setiap desa di daerah kabupaten/ kota tahun anggaran 2019 dihitung dengan menggunakan formula sebagai berikut: ${ }^{9}$

AD Desa $2019=\frac{\text { AD } 2019}{\mathrm{D}}$

Keterangan:

AD Desa 2019 : Alokasi Dasar setiap desa di daerah kabupaten/ kota tahun anggaran 2019

AD 2019 : pagu Alokasi Dasar tahun anggaran 2019

D : jumlah desa nasional yang merupakan jumlah Desa yang disampaikan oleh Kementerian Dalam Negeri

6 Ibid., Pasal 10.

7 Ibid., Pasal 7.

8 lbid., Pasal 8.

9 lbid. 
(KEMENDAGRI) kepada Kementerian Keuangan (KEMENKEU).

\section{b. Alokasi Afirmasi setiap Daerah Kabupaten/ Kota Tahun Anggaran 2019}

Alokasi Afirmasi setiap daerah kabupaten/ kota tahun anggaran 2019 dihitung dengan menggunakan formula sebagai berikut: ${ }^{10}$

AA Kab/ Kota $2019=($ AA DST $2019 \times$ DST Kab/ Kota $)+($ AA DT

dimana:

$$
2019 \times \text { DT Kab/ Kota) }
$$

AA Kab/ Kota 2019: Alokasi Afirmasi setiap daerah kabupaten/ kota tahun anggaran 2019

AA DST 2019 : besaran Alokasi Afirmasi untuk Desa Sangat Tertinggal (DST) yang memiliki jumlah penduduk miskin tinggi, dimana besarnya adalah dua kali Alokasi Afirmasi setiap desa tahun anggaran 2019

DST Kab/Kota :jumlah Desa Sangat Tertinggal (DST) yang memiliki jumlah penduduk miskin tinggi di daerah kabupaten/ kota

AA DT 2019 : besaran Alokasi Afirmasi untuk Desa Tertinggal (DT) yang memiliki jumlah penduduk miskin tinggi, dimana besarnya adalah satu kali Alokasi Afirmasi setiap desa tahun anggaran 2019

DT Kab/ Kota : jumlah Desa Tertinggal (DT) yang memiliki jumlah penduduk miskin tinggi di daerah kabupaten/ kota

\section{c. Alokasi Formula setiap Daerah Kabupaten/ Kota Tahun} Anggaran 2019

Alokasi Formula setiap daerah kabupaten/ kota tahun anggaran 2019 dihitung dengan menggunakan formula sebagai berikut: ${ }^{11}$

$\mathrm{AF} \mathrm{Kab} /$ Kota $2019=[(0.10 \times \mathrm{A} 1)+(0.50 \times \mathrm{A} 2)+(0.15 \times \mathrm{A} 3)+(0.25$

dimana:

$$
\text { x A4)] x (0.25 x DD 2019) }
$$

AF Kab/ Kota 2019 :Alokasi Formula setiap daerah kabupaten/ kota tahun anggaran 2019 :rasio jumlah penduduk desa setiap daerah kabupaten/ kota terhadap total penduduk desa nasional

$10 \mathrm{lbid} .$, Pasal 9.

11 lbid., Pasal 10. 
: rasio jumlah penduduk miskin desa setiap daerah kabupaten/ kota terhadap total penduduk miskin desa nasional

A3

: rasio luas wilayah desa setiap daerah kabupaten/ kota terhadap total luas wilayah desa nasional

: rasio IKK daerah kabupaten/ kota terhadap total

DD 2019 IKK daerah kabupaten/ kota yang memiliki desa. : pagu Dana Desa nasional tahun anggaran 2019

\section{Pengalokasian Dana Desa setiap Desa di Daerah Kabupaten/ Kota Tahun Anggaran 2019}

Berdasarkan rincian Dana Desa setiap daerah kabupaten/ kota tahun anggaran 2019, bupati/ wali kota melakukan perhitungan rincian Dana Desa setiap desa tahun anggaran 2019. Besaran Dana Desa setiap desa di daerah kabupaten/ kota dialokasikan secara merata dan berkeadilan berdasarkan tiga jenis alokasi, yaitu Alokasi Dasar setiap desa, Alokasi Afirmasi setiap desa, dan Alokasi Formula setiap desa. ${ }^{12}$

Dana Desa setiap desa di daerah kabupaten/ kota tahun anggaran 2019 dihitung dengan menggunakan formula sebagai berikut: ${ }^{13}$

DD Desa 2019 = AD Desa $2019+$ AA Desa $2019+$ AF Desa 2019 dimana:

DD Desa 2019 : Dana Desa setiap desa di Daerah kabupaten/ kota tahun anggaran 2019

AD Desa 2019 : Alokasi Dasar setiap desa di Daerah kabupaten/ kota tahun anggaran 2019

AA Desa 2019 : Alokasi Afirmasi setiap desa di Daerah kabupaten/ kota tahun anggaran 2019

AF Desa 2019 : Alokasi Formula setiap desa di Daerah kabupaten/ kota tahun anggaran 2019

\section{a. Alokasi Dasar setiap Desa di Daerah Kabupaten/ Kota Tahun Anggaran 2019}

Dari persamaan (2), dapat diketahui bahwa Alokasi Dasar setiap desa di daerah kabupaten/ kota tahun anggaran 2019 dihitung dengan menggunakan formula sebagai berikut: ${ }^{14}$

AD Desa $2019=\underline{\text { AD Kab } / \text { Kota } 2019}$

$\mathrm{D} \mathrm{Kab} / \mathrm{Kota}$

dimana:

AD Desa 2019 : Alokasi Dasar setiap desa di daerah kabupaten/ kota tahun anggaran 2019

12 lbid., Pasal 11.

$13 \mathrm{lbid}$.

14 Ibid., Pasal 12. 
AD Kab/ Kota 2019:Alokasi Dasar setiap daerah kabupaten/ kota tahun anggaran 2019

D Kab/ Kota : :jumlah desa di daerah kabupaten/ kota

Jika jumlah desa di daerah kabupaten/ kota berbeda dengan data jumlah desa dari Kementerian Dalam Negeri, maka bupati/ wali kota menyampaikan pemberitahuan mengenai perbedaan jumlah desa tersebut kepada Menteri Dalam Negeri dengan tembusan kepada Menteri Keuangan c.q. Direktur Jenderal Perimbangan Keuangan. ${ }^{15}$

Jika jumlah desa di daerah kabupaten/ kota lebih sedikit daripada jumlah desa berdasarkan data dari Kementerian Dalam Negeri, maka bupati/ wali kota menghitung dan menetapkan Dana Desa setiap desa di kabupaten/ kota dengan mengurangkan Alokasi Dasar daerah kabupaten/ kota dengan Alokasi Dasar untuk selisih jumlah desa tersebut. Selanjutnya, jika jumlah desa di daerah kabupaten/ kota lebih banyak daripada jumlah desa berdasarkan data dari Kementerian Dalam Negeri, maka bupati/ wali kota menghitung dan menetapkan Dana Desa setiap desa di kabupaten/ kota dengan menggunakan jumlah desa dari Kementerian Dalam Negeri. ${ }^{16}$

\section{b. Alokasi Afirmasi setiap Desa di Daerah Kabupaten/ Kota Tahun Anggaran 2019}

Alokasi Afirmasi setiap desa di daerah kabupaten/ kota tahun anggaran 2019 dihitung dengan menggunakan formula sebagai berikut: ${ }^{17}$ AA Desa $2019=(0.03 \times$ DD 2019) [(2 x DST) $(1 \times$ DT) $]$

Keterangan:

AA Desa 2019 : Alokasi Afirmasi setiap desa di daerah kabupaten/ kota tahun anggaran 2019

DD 2019 :pagu Dana Desa tahun anggaran 2019

DST : jumlah Desa Sangat Tertinggal (DST) yang memiliki jumlah penduduk miskin tinggi

DT :jumlah Desa Tertinggal (DT) yang memiliki jumlah penduduk miskin tinggi.

\section{c. Alokasi Formula setiap Desa di Daerah Kabupaten/ Kota Tahun Anggaran 2019}

Besarnya Alokasi Formula setiap desa di kabupaten/ kota tahun anggaran 2019 dihitung berdasarkan bobot, yaitu 10\% untuk jumlah

$15 \mathrm{lbid}$.

16 lbid.

17 lbid., Pasal 9. 
penduduk, 50\% untuk angka kemiskinan, 15\% untuk luas wilayah, dan $25 \%$ untuk tingkat kesulitan geografis. ${ }^{18}$

Alokasi Formula setiap desa di daerah kabupaten/ kota tahun anggaran 2019 dihitung dengan menggunakan formula sebagai berikut: ${ }^{19}$ AF Desa $2019=[(0.10 \times$ B1 $)+(0.50 \times$ B2 $)+(0.15 \times$ B3 $)+(0.25 \times$ B4 $)]$ x AF Kab/ Kota 2019

dimana:

AF Desa 2019 : Alokasi Formula setiap desa di daerah kabupaten/ kota tahun anggaran 2019

B1

: rasio jumlah penduduk setiap desa terhadap total penduduk desa daerah kabupaten/ kota

B2

: rasio jumlah penduduk miskin setiap desa terhadap total penduduk miskin desa daerah kabupaten/ kota

B3

: rasio luas wilayah setiap desa terhadap total luas wilayah desa daerah kabupaten/ kota

B4

: rasio IKG setiap desa terhadap total IKG desa daerah kabupaten/ kota

AF Kab/ Kota 2019 :Alokasi Formula setiap daerah kabupaten/ kota tahun anggaran 2019

Angka kemiskinan desa ditunjukkan oleh jumlah penduduk miskin desa, sedangkan tingkat kesulitan geografis desa ditunjukkan oleh Indeks Kesulitan Geografis (IKG) desa. ${ }^{20}$ IKG desa adalah angka yang mencerminkan tingkat kesulitan geografis suatu desa berdasarkan variabel ketersediaan pelayanan dasar, kondisi infrastruktur, transportasi, dan komunikasi. ${ }^{21}$ IKG desa tersebut disusun dan ditetapkan oleh bupati/ wali kota berdasarkan dari Badan Pusat Statistik (BPS).22

\section{B. Pengalokasian Dana Desa Tahun Anggaran 2020}

Pembahasan mengenai pengalokasian Dana Desa Tahun Anggaran 2020 dibagi menjadi dua bagian, yaitu pengalokasian Dana Desa setiap daerah kabupaten/ kota tahun anggaran 2020 dan pengalokasian Dana Desa setiap desa di daerah kabupaten/ kota tahun anggaran 2020 sebagai berikut:

1. Pengalokasian Dana Desa setiap Daerah Kabupaten /Kota Tahun Anggaran 2020

Besaran Dana Desa setiap daerah kabupaten/ kota tahun anggaran 2020 dialokasikan secara merata dan berkeadilan berdasarkan empat jenis alokasi, yaitu Alokasi Dasar, Alokasi Afirmasi, Alokasi Kinerja, dan Alokasi

\footnotetext{
18 Ibid., Pasal 14.

$19 \mathrm{lbid}$.

20 lbid.

21 lbid., Pasal 1.

22 Ibid., Pasal 14.
} 
Formula. Pagu Alokasi Dasar besarnya adalah 69\% dari anggaran Dana Desa yang dibagi sama rata kepada setiap desa secara nasional. Desa secara nasional adalah jumlah desa mutakhir yang bersumber dari Kementerian Dalam Negeri. Pagu Alokasi Afirmasi besarnya adalah 1.5\% dari anggaran Dana Desa yang dibagi secara proporsional kepada Desa Tertinggal (DT) dan Desa Sangat Tertinggal (DST) yang memiliki jumlah penduduk miskin tinggi, yaitu Desa Tertinggal dan Desa Sangat Tertinggal yang memiliki jumlah penduduk miskin terbanyak yang berada pada desil ke delapan, sembilan, dan sepuluh berdasarkan perhitungan dari Direktorat Jenderal Perimbangan Keuangan. Status Desa Tertinggal dan Desa Sangat Tertinggal tersebut ditetapkan berdasarkan data Indeks Desa Membangun (IDM) yang diterbitkan oleh Kementerian Desa, Pembangunan Daerah Tertinggal, dan Transmigrasi Republik Indonesia, dan data jumlah penduduk miskin yang digunakan adalah data dari Badan Pusat Statistik (BPS) atau Kementerian Sosial Republik Indonesia. ${ }^{23}$

Pagu Alokasi Kinerja besarnya adalah 1.5\% dari anggaran Dana Desa yang dibagikan kepada desa dengan kinerja terbaik. Desa dengan kinerja terbaik tersebut adalah sebanyak 10\% dari jumlah desa yang memiliki hasil penilaian kinerja terbaik berdasarkan bobot tertentu, yaitu $20 \%$ untuk pengelolaan keuangan desa, 20\% untuk pengelolaan Dana Desa, 25\% untuk capaian keluaran Dana Desa, 35\% untuk capaian hasil pembangunan desa. ${ }^{24}$

Selanjutnya, Pagu Alokasi Formula besarnya adalah 28\% dari anggaran Dana Desa yang dibagi kepada desa berdasarkan bobot yang berbeda, yaitu 10\% untuk jumlah penduduk desa, 50\% untuk angka kemiskinan desa, 15\% untuk luas wilayah desa, dan 25\% untuk tingkat kesulitan geografis desa. ${ }^{25}$ Data jumlah penduduk desa, angka kemiskinan desa, luas wilayah desa, dan IKK daerah kabupaten/ kota tersebut diperoleh dari Kementerian Dalam Negeri Republik Indonesia, Kementerian Sosial Republik Indonesia, dan/atau Badan Pusat Statistik (BPS). Jika data tersebut tidak tersedia, maka dapat digunakan data dari data desa induk secara proporsional atau data yang bersumber dari Pemerintah Daerah. ${ }^{26}$ Angka kemiskinan desa dilihat dari jumlah penduduk miskin desa, sedangkan tingkat kesulitan geografis desa dilihat dari Indeks Kemahalan Konstruksi (IKK) daerah kabupaten/ kota. ${ }^{27}$ IKK adalah indeks yang mencerminkan tingkat kesulitan geografis yang dinilai berdasarkan tingkat kemahalan harga prasarana fisik secara relatif antar daerah. ${ }^{28}$

\footnotetext{
${ }^{23}$ Peraturan Menteri Keuangan Republik Indonesia Nomor 40/PMK.07/2020 tentang Pengelolaan Dana Desa, pasal 6.

24 lbid.

25 lbid.

26 Ibid., Pasal 13.

${ }^{27} \mathrm{Ibid}$., Pasal 6.

$28 \mathrm{lbid}$., Pasal 1.
} 
Dana Desa setiap daerah kabupaten/ kota tahun anggaran 2020 dihitung dengan menggunakan formula sebagai berikut: ${ }^{29}$

DD Kab/ Kota $2020=$

$\mathrm{Kab} /$ Kota $2020+\mathrm{AA} \mathrm{Kab} /$ Kota $2020+\mathrm{AK} \mathrm{Kab} /$

Kota $2020+$ AF Kab/ Kota 2020

dimana:

DD Kab/ Kota 2020: Dana Desa setiap Daerah kabupaten/ kota tahun anggaran 2020

AD Kab/ Kota 2020: Alokasi Dasar setiap Daerah kabupaten/ kota tahun anggaran 2020

AA Kab/Kota 2020: Alokasi Afirmasi setiap Daerah kabupaten/ kota tahun anggaran 2020

AK Kab/ Kota 2020 : Alokasi Kinerja setiap Daerah kabupaten/ kota tahun anggaran 2020

AF Kab/ Kota 2020 : Alokasi Formula setiap Daerah kabupaten/ kota tahun anggaran 2020

a. Alokasi Dasar setiap Daerah Kabupaten/ Kota Tahun Anggaran 2020

Alokasi Dasar setiap daerah kabupaten/ kota tahun anggaran 2020 dihitung dengan menggunakan formula sebagai berikut: 30

AD Kab/ Kota $2020=$ AD Desa 2020 x D Kab/ Kota dimana:

AD Kab/ Kota 2020:Alokasi Dasar setiap daerah kabupaten/ kota tahun anggaran 2020

AD Desa 2020 :Alokasi Dasar setiap desa di daerah kabupaten/ kota tahun anggaran 2020

D Kab/ Kota : :jumlah desa di daerah kabupaten/ kota

Selanjutnya, Alokasi Dasar setiap desa di daerah kabupaten/ kota tahun anggaran 2020 dihitung dengan menggunakan formula sebagai berikut: ${ }^{31}$

AD Desa $2020=\underline{\text { AD } 2020}$

Keterangan:

AD Desa 2020 : Alokasi Dasar setiap desa di daerah kabupaten/ kota tahun anggaran 2020

AD 2020 : pagu Alokasi Dasar tahun anggaran 2020

D : jumlah desa secara nasional

29 lbid., Pasal 9.

30 lbid., Pasal 10.

$31 \mathrm{lbid}$. 


\section{b. Alokasi Afirmasi setiap Daerah Kabupaten/ Kota Tahun Anggaran 2020}

Alokasi Afirmasi setiap daerah kabupaten/ kota tahun anggaran 2020 dihitung dengan menggunakan formula sebagai berikut: ${ }^{32}$

AA Kab $/$ Kota $2020=($ AA DST $2020 \times$ DST Kab $/$ Kota $)+($ AA DT

$$
2020 \text { x DT Kab/ Kota) }
$$

dimana:

AA Kab/ Kota 2020 :Alokasi Afirmasi setiap daerah kabupaten/ kota tahun anggaran 2020

AA DST 2020 :besaran Alokasi Afirmasi untuk Desa Sangat Tertinggal (DST) yang memiliki jumlah penduduk miskin tinggi, dimana besarnya adalah dua kali Alokasi Afirmasi setiap desa tahun anggaran 2020

DST Kab/ Kota :jumlah Desa Sangat Tertinggal (DST) yang memiliki jumlah penduduk miskin tinggi di daerah kabupaten/ kota

AA DT 2020 :besaran Alokasi Afirmasi untuk Desa Tertinggal (DT) yang memiliki jumlah penduduk miskin tinggi, dimana besarnya adalah satu kali Alokasi Afirmasi setiap desa tahun anggaran 2020

DT Kab/ Kota :jumlah Desa Tertinggal (DT) yang memiliki jumlah penduduk miskin tinggi di daerah kabupaten/ kota

\section{c. Alokasi Kinerja setiap Daerah Kabupaten/ Kota Tahun Anggaran 2020}

Alokasi Kinerja setiap daerah kabupaten/ kota tahun anggaran 2020 dihitung dengan menggunakan formula sebagai berikut: ${ }^{33}$

AK Kab/ Kota $2020=$ DAK Kab/ Kota x AK Desa 2020 dimana:

AK Kab/ Kota 2020: Alokasi Kinerja setiap daerah kabupaten/ kota tahun anggaran 2020

DAK Kab/Kota : jumlah desa penerima Alokasi Kinerja setiap $\mathrm{Kab} /$ Kota

AK Desa 2020 : Alokasi Kinerja setiap desa di daerah kabupaten/ kota tahun anggaran 2020

Jika $0 \leq$ jumlah desa di daerah kab/ kota $\leq 100$ maka jumlah desa penerima Alokasi Kinerja adalah 11\% dari jumlah desa di daerah kab/ kota. Jika $101 \leq$ jumlah desa di daerah kab/ kota $\leq 400$ maka jumlah desa penerima Alokasi Kinerja adalah 10\% dari jumlah desa di daerah

32 lbid., Pasal 11.

33 Ibid., Pasal 12. 
kab/ kota. Selanjutnya, iika jumlah desa di daerah kab/ kota $>400$ maka jumlah desa penerima Alokasi Kinerja adalah 9\% dari jumlah desa di daerah kab/ kota. ${ }^{34}$

Penerima Alokasi Kinerja tersebut ditentukan dari urutan Skor Kinerja setiap desa di daerah kabupaten/ kota yang dihitung dengan menggunakan formula sebagai berikut: ${ }^{35}$

Skor Kinerja $=[(0.20 \times \mathrm{C} 1)+(0.20 \times \mathrm{C} 2)+(0.25 \times \mathrm{C} 3)+(0.35 \times \mathrm{C} 4)]$

dimana:

Skor Kinerja : Skor Kinerja setiap desa

C1 : pengelolaan keuangan desa

C2 : pengelolaan Dana Desa

C3 : capaian keluaran Dana Desa

C4 : capaian hasil pembangunan desa

Pengelolaan keuangan desa dinilai dari perubahan rasio Pendapatan Asli Desa (PADes) terhadap total pendapatan pada Anggaran Pendapatan dan Belanja Desa (APBDes) dan rasio belanja bidang pembangunan dan pemberdayaan terhadap total belanja bidang pada APBDes yang masing-masing mempunyai bobot 50\%. ${ }^{36}$ Data APBDes tersebut bersumber dari Kementerian Desa, Pembangunan Daerah Tertinggal, dan Transmigrasi Republik Indonesia. ${ }^{37}$

Pengelolaan Dana Desa dinilai dari persentase kesesuaian bidang pembangunan dan pemberdayaan sebagai bidang prioritas penggunaan Dana Desa terhadap total Dana Desa setiap desa dan persentase pengadaan barang dan jasa Dana Desa secara swakelola yang masingmasing mempunyai bobot $55 \%$ dan $45 \% .^{38}$

Capaian keluaran Dana Desa dinilai dari persentase realisasi penyerapan Dana Desa dan persentase capaian keluaran Dana Desa yang masing-masing mempunyai bobot 50\%. Selanjutnya, capaian hasil pembangunan desa dinilai dari perubahan skor Indeks Desa Membangun (IDM), perubahan status desa IDM, status desa IDM terakhir, dan perbaikan jumlah penduduk miskin desa yang masing-masing mempunyai bobot 30\%, 30\%, 10\%, dan 30\%. Data mengenai realisasi penyerapan dan capaian keluaran Dana Desa tersebut bersumber dari aplikasi yang disediakan oleh Direktorat Jenderal Perbendaharaan. ${ }^{39}$

34 Ibid.

$35 \mathrm{lbid}$.

$36 \mathrm{lbid}$.

$37 \mathrm{lbid}$.

$38 \mathrm{lbid}$.

39 lbid. 


\section{d. Alokasi Formula setiap Daerah Kabupaten/ Kota Tahun Anggaran 2020}

Alokasi Formula setiap daerah kabupaten/ kota tahun anggaran 2020 dihitung dengan menggunakan formula sebagai berikut: ${ }^{40}$

$\mathrm{AF} \mathrm{Kab} /$ Kota $2020=[(0.10 \times \mathrm{D} 1)+(0.50 \times \mathrm{D} 2)+(0.15 \times \mathrm{D} 3)+(0.25$

dimana:

$$
\text { x D4)] } \mathrm{x}(0.28 \times \text { DD 2020) }
$$

AF Kab/ Kota 2020 :Alokasi Formula setiap daerah kabupaten/ kota tahun anggaran 2020

D1 :rasio jumlah penduduk desa setiap daerah kabupaten/ kota terhadap total penduduk desa nasional

D2 :rasio jumlah penduduk miskin desa setiap daerah kabupaten/ kota terhadap total penduduk miskin desa nasional

D3 :rasio luas wilayah desa setiap daerah kabupaten/ kota terhadap total luas wilayah desa nasional

D4

DD 2020 :rasio IKK daerah kabupaten/ kota terhadap total IKK daerah kabupaten/ kota yang memiliki desa. :pagu Dana Desa nasional tahun anggaran 2020

\section{Formula Pengalokasian Dana Desa setiap Desa di Daerah Kabupaten/ Kota Tahun Anggaran 2020}

Berdasarkan rincian Dana Desa setiap daerah kabupaten/ kota tahun anggaran 2020, bupati/ wali kota melakukan perhitungan rincian Dana Desa setiap desa tahun anggaran 2020. Besaran Dana Desa setiap desa di daerah kabupaten/ kota dialokasikan secara merata dan berkeadilan berdasarkan empat jenis alokasi, yaitu Alokasi Dasar setiap desa, Alokasi Afirmasi setiap desa, Alokasi Kinerja setiap desa, dan Alokasi Formula setiap desa. ${ }^{41}$

Dana Desa setiap desa di daerah kabupaten/ kota tahun anggaran 2020 dihitung dengan menggunakan formula sebagai berikut: 42

DD Desa $2020=A D$ Desa $2020+$ AA Desa $2020+$ AK Desa $2020+$ AF Desa 2020

dimana:

DD Desa 2020 : Dana Desa setiap desa di Daerah kabupaten/ kota tahun anggaran 2020

AD Desa 2020 : Alokasi Dasar setiap desa di Daerah kabupaten/ kota tahun anggaran 2020

\footnotetext{
40 Ibid., Pasal 13.

41 lbid., Pasal 14.

42 lbid.
} 
AA Desa 2020 : Alokasi Afirmasi setiap desa di Daerah kabupaten/ kota tahun anggaran 2020

AK Desa 2020 : Alokasi Kinerja setiap desa di Daerah kabupaten/ kota tahun anggaran 2020

AF Desa 2020 : Alokasi Formula setiap desa di Daerah kabupaten/ kota tahun anggaran 2020

\section{a. Alokasi Dasar setiap Desa di Daerah Kabupaten/ Kota Tahun Anggaran 2020}

Dari persamaan (11), dapat diketahui bahwa Alokasi Dasar setiap desa di daerah kabupaten/ kota tahun anggaran 2020 dihitung dengan menggunakan formula sebagai berikut: ${ }^{43}$

AD Desa $2020=\underline{\text { AD Kab } / \text { Kota } 2020}$

D Kab/ Kota

dimana:

AD Desa 2020 : Alokasi Dasar setiap desa di daerah kabupaten/ kota tahun anggaran 2020

AD Kab/ Kota 2020: Alokasi Dasar setiap daerah kabupaten/ kota tahun anggaran 2020

D Kab/ Kota : jumlah desa di daerah kabupaten/ kota

Bupati/ wali kota memverifikasi data jumlah desa di daerah kabupaten/ kotanya dengan cara membandingkan data jumlah desa dalam Alokasi Dana Desa pada tahun sebelumnya dengan jumlah desa secara nasional yang merupakan jumlah desa mutakhir yang bersumber dari Kementerian Dalam Negeri, dan hasil verifikasi tersebut disampaikan kepada Menteri Dalam Negeri dan Menteri Keuangan c.q. Direktur Jenderal Perimbangan Keuangan paling lambat bulan Agustus sebelum tahun anggaran berjalan. ${ }^{44}$

Jika jumlah desa di daerah kabupaten/ kota lebih sedikit daripada jumlah desa berdasarkan data dari Kementerian Dalam Negeri, maka bupati/ wali kota menghitung dan menetapkan rincian Dana Desa setiap desa di kabupaten/ kota dengan mengurangkan Alokasi Dasar daerah kabupaten/ kota dengan Alokasi Dasar untuk selisih jumlah desa tersebut. Selanjutnya, jika jumlah desa di daerah kabupaten/ kota lebih banyak daripada jumlah desa berdasarkan data dari Kementerian Dalam Negeri, maka bupati/ wali kota menghitung dan menetapkan Dana Desa setiap desa di kabupaten/ kota dengan menggunakan jumlah desa dari Kementerian Dalam Negeri. ${ }^{45}$

43 Ibid., Pasal 15.

44 Ibid., Pasal 7.

45 lbid., Pasal 15. 
b. Alokasi Afirmasi setiap Desa di Daerah Kabupaten/ Kota Tahun Anggaran 2020

Alokasi Afirmasi setiap desa di daerah kabupaten/ kota tahun anggaran 2020 dihitung dengan menggunakan formula sebagai berikut: ${ }^{46}$ AA Desa $2020=\underline{(0.015 \times \text { DD 2020 })}$

$$
[(2 \times \mathrm{DST})(1 \times \mathrm{DT})]
$$

Keterangan:

AA Desa 2020 : Alokasi Afirmasi setiap desa di daerah kabupaten/ kota tahun anggaran 2020

DD 2020 : pagu Dana Desa nasional tahun anggaran 2020

DST : jumlah Desa Sangat Tertinggal (DST) yang memiliki jumlah penduduk miskin tinggi

DT : jumlah Desa Tertinggal (DT) yang memiliki jumlah penduduk miskin tinggi.

\section{c. Alokasi Kinerja setiap Desa di Daerah Kabupaten/ Kota Tahun} Anggaran 2020

Alokasi Kinerja setiap desa di daerah kabupaten/ kota tahun anggaran 2020 dihitung dengan menggunakan formula sebagai berikut: ${ }^{47}$ AK Desa $2020=(0.015 \times$ DD 2020 $)$

$$
(0.1 \times \mathrm{D})
$$

Keterangan:

AK Desa 2020 : Alokasi Kinerja setiap desa di daerah kabupaten/ kota tahun anggaran 2020

DD 2020 : pagu Dana Desa nasional tahun anggaran 2020

D : jumlah desa nasional

\section{d. Alokasi Formula setiap Desa di Daerah Kabupaten/ Kota} Tahun Anggaran 2020

Besarnya Alokasi Formula setiap desa di kabupaten/ kota tahun anggaran 2020 dihitung berdasarkan bobot tertentu, yaitu 10\% untuk jumlah penduduk, 50\% untuk angka kemiskinan, 15\% untuk luas wilayah, dan $25 \%$ untuk tingkat kesulitan geografis. ${ }^{48}$

Alokasi Formula setiap desa di daerah kabupaten/ kota tahun anggaran 2020 dihitung dengan menggunakan formula sebagai berikut: ${ }^{49}$ AF Desa $2020=[(0.10 \times$ E1 $)+(0.50 \times$ E2 $)+(0.15 \times$ E3 $)+(0.25 \times$ E4 $)]$ x AF Kab/ Kota 2020

dimana:

\footnotetext{
46 Ibid., Pasal 11.

47 Ibid., Pasal 12.

48 lbid., Pasal 18.

49 lbid.
} 
AF Desa 2020 : Alokasi Formula setiap desa di daerah kabupaten/ kota tahun anggaran 2020

E1 : rasio jumlah penduduk setiap desa terhadap total penduduk desa daerah kabupaten/ kota

E2 : rasio jumlah penduduk miskin setiap desa terhadap total penduduk miskin desa daerah kabupaten/ kota

E3 : rasio luas wilayah setiap desa terhadap total luas wilayah desa daerah kabupaten/ kota

E4 : rasio IKG setiap desa terhadap total IKG desa daerah kabupaten/ kota

AF Kab/ Kota 2020 : Alokasi Formula setiap daerah kabupaten/ kota tahun anggaran 2020

Angka kemiskinan desa ditunjukkan oleh jumlah penduduk miskin desa, sedangkan tingkat kesulitan geografis desa ditunjukkan oleh Indeks Kesulitan Geografis (IKG) desa. ${ }^{50}$ IKG desa adalah angka yang mencerminkan tingkat kesulitan geografis suatu desa berdasarkan variabel ketersediaan pelayanan dasar, kondisi infrastruktur, transportasi, dan komunikasi. ${ }^{51}$ IKG desa tersebut bersumber dari Badan Pusat Statistik (BPS). 52

\section{Perbedaan Pengalokasian Dana Desa pada Tahun Anggaran 2019 dan 2020}

Perbedaan pengalokasian Dana Desa Tahun Anggaran 2019 dan 2020 dapat dilihat dalam tabel berikut:

Tabel 1.

\begin{tabular}{|c|c|}
\hline $\begin{array}{c}\text { Pengalokasian Dana Desa } \\
\text { Tahun Anggaran } 2019\end{array}$ & $\begin{array}{c}\text { Pengalokasian Dana Desa Tahun } \\
\text { Anggaran } 2020\end{array}$ \\
\hline $\begin{array}{l}\text { Rincian Dana Desa setiap daerah } \\
\text { kabupaten/ kota dialokasikan } \\
\text { berdasarkan tiga jenis alokasi, yaitu } \\
\text { Alokasi Dasar, Alokasi Afirmasi, } \\
\text { dan Alokasi Formula }\end{array}$ & $\begin{array}{l}\text { Rincian Dana Desa setiap daerah } \\
\text { kabupaten/ kota dialokasikan } \\
\text { berdasarkan empat jenis alokasi, yaitu } \\
\text { Alokasi Dasar, Alokasi Afirmasi, } \\
\text { Alokasi Kinerja, dan Alokasi Formula }\end{array}$ \\
\hline $\begin{array}{l}\text { Pagu Alokasi Dasar adalah sebesar } \\
72 \% \text { dari anggaran Dana Desa yang } \\
\text { dibagikan secara merata kepada } \\
\text { setiap desa }\end{array}$ & $\begin{array}{l}\text { Pagu Alokasi Dasar adalah sebesar } \\
\text { 69\% dari anggaran Dana Desa yang } \\
\text { dibagikan secara merata kepada setiap } \\
\text { desa }\end{array}$ \\
\hline
\end{tabular}

$50 \mathrm{lbid}$.

51 lbid., Pasal 1.

52 lbid., Pasal 18. 
Pagu Alokasi Afirmasi adalah sebesar 3\% dari anggaran Dana Desa yang dibagikan secara proporsional kepada desa tertinggal dan sangat tertinggal yang mempunyai jumlah penduduk miskin tinggi

Tidak terdapat pagu Alokasi Kinerja

Pagu Alokasi Formula adalah sebesar 25\% dari anggaran Dana Desa yang dibagikan berdasarkan jumlah penduduk, angka kemiskinan, luas wilayah dan tingkat kesulitan geografis
Pagu Alokasi Afirmasi adalah sebesar $1.5 \%$ dari anggaran Dana Desa yang dibagikan secara proporsional kepada desa tertinggal dan sangat tertinggal yang mempunyai jumlah penduduk miskin tinggi

Pagu Alokasi Kinerja adalah sebesar 1.5\% dari anggaran Dana Desa yang dibagikan kepada 10\% desa yang memiliki skor kinerja terbaik berdasarkan pengelolaan keuangan desa, pengelolaan Dana Desa, capaian keluaran Dana Desa, dan capaian hasil pembangunan desa yang memiliki bobot masing-masing sebesar 20\%, 20\%, 25\% , dan 35\% Pagu Alokasi Formula adalah sebesar 28\% dari anggaran Dana Desa yang dibagikan berdasarkan jumlah penduduk, angka kemiskinan, luas wilayah dan tingkat kesulitan geografis

\section{Faktor-Faktor yang Menyebabkan Perubahan Formula Pengalokasian Dana Desa pada Tahun Anggaran 2020}

Faktor-faktor yang menyebabkan perubahan formula pengalokasian Dana Desa pada tahun anggaran 2020 adalah sebagai berikut:

1. Terdapat desa yang tidak menginginkan kenaikan status desa karena akan kehilangan Alokasi Afirmasi

Bagi desa yang statusnya naik dari tertinggal atau sangat tertinggal maka desa tersebut tidak akan mendapatkan Alokasi Afirmasi, yang mengakibatkan total Dana Desa (DD) yang diterima akan berkurang. Ada beberapa desa yang lebih memilih status desanya tertinggal atau sangat tertinggal, walaupun sebenarnya status desanya sudah naik, karena menginginkan tambahan Dana Desa lewat Alokasi Afirmasi. ${ }^{53}$

Salah satu dasar dalam perhitungan pengalokasian Dana Desa (DD) adalah dengan menggunakan Indeks Desa Membangun (IDM) yang dimiliki oleh Kementerian Desa, Pembangunan Daerah Tertinggal dan Transmigrasi Republik Indonesia. Proses Pendataaan IDM dilakukan

53 Wawancara dengan Muhamad Ulil Albab, selaku Tenaga Ahli Pembangunan Partisipatif Kabupaten Purbalingga, pada tanggal 29 April 2020 pukul 10.00 WIB 
untuk kebutuhan tahun selanjutnya atau $(n+1)$ yang dilakukan setiap tahun. IDM merupakan seperangkat cara perhitungan yang dilakukan dengan melakukan pendataan mengisi dan menjawab pertanyaan yang sudah disediakan. Pengisian data ini dilakukan langsung oleh Pemerintah Desa disertai tandatangan, stempel dan bermaterai. Salah satu output dari IDM adalah munculnya status masing-masing desa, mulai sangat tertinggal, tertinggal, berkembang, dan maju. ${ }^{54}$

Cara perhitungan dengan menggunakan IDM dianggap merupakan cara yang efektif, akurat, dan lengkap untuk mengumpulkan data di desadesa di seluruh wilayah Indonesia karena dilakukan langsung oleh desa yang bersangkutan. Akan tetapi IDM juga memiliki kekurangan, salah satunya adalah bagi desa yang mengetahui formula perhitungan Dana Desa yang didalamnya terdapat komponen yang berhubungan dengan Alokasi Afirmasi, maka akan dipakai sebagai celah. Hal ini dikarenakan ketika status desanya tidak termasuk sangat tertinggal dan tertinggal maka desa tersebut tidak mendapatkan Alokasi Afirmasi yang akan menyebabakan berkurangnya jumlah total dari Dana Desa (DD) yang diterima. 55

2. Evaluasi dari pemerintah untuk menurunkan persentase Alokasi Dasar agar lebih mencerminkan keadilan dan kondisi desa

Pemerintah melalui Kementerian Keuangan melakukan perhitungan dan formulasi penentuan besaran alokasi Dana Desa (DD) yang diberian ke Desa. salah satu formulasi yang diguakan adalah adanya Alokasi Dasar. Alokasi Dasar merupakan Alokasi yang diberikan ke Desa seluruh Indonesia dengan besaran yang sama. ${ }^{56}$

Salah satu evaluasi yang dilakukan Kementerian Keuangan atas masukan dari Kementerian Desa, Pembanguan Daerah Tertinggal dan Transmigrasi adalah menurunkan persentase Alokasi Dasar dan menambah persentase untuk alokasi yang lain yang lebih mencerminkan kondisi riil setiap desa. ${ }^{57}$

3. Evaluasi dari pemerintah untuk menaikkan Alokasi Formula agar lebih mencerminkan kondisi riil desa berdasarkan jumlah penduduk, jumlah penduduk miskin, luas wilayah, dan indeks kesulitan geografis

Salah satu evaluasi Pemerintah melalui Kementerian Keuangan dalam perhitungan Dana Desa (DD) adalah dalam penentuan persentase Aloksi Formula. Alokasi Formula adalah perhitungan yang dilakukan 
berdasarkan kondisi riil desa berdasarkan jumlah penduduk, jumlah penduduk miskin, luas wilayah, dan indeks kesulitan geografis. Perhitungan tersebut akan menyesuaikan kondisi masing-masing desa dan alokasi yang diterima masing-masing desa akan berbeda-beda. ${ }^{58}$

Dalam melakukan perhitungan dan formulasi Dana Desa (DD) Kementerian Keuangan di tahun anggaran 2019 melakukan evaluasi dengan mengurangi Alokasi Dasar dan menambahkan persentase Alokasi Formula. Pemerintah melihat bahwa ketika menambahkan presentase Alokasi Formula maka akan lebih objektif dan adil karena Alokasi Formula merupakan hasil perhitungan dari data riil lapangan desa yang berdasarkan jumlah penduduk, jumlah penduduk miskin, luas wilayah, dan indeks kesulitan geografis. ${ }^{59}$

4. Pemberian apresiasi/reward dari pemerintah berupa pemberian Alokasi Kinerja kepada desa-desa yang memiliki kinerja terbaik.

Kebijakan Pemeritah dalam pemberian bantuan dari APBN kepada desa melalui Dana Desa (DD) masih tergolong baru, karena baru 5 tahun berjalan, maka dari itu masih diperlukan penyesuaian dan perbaikan setiap tahunnya. Usaha perbaikan ini dilakukan lintas kementerian dikarenakan kebijakan terkait Dana Desa melibatkan beberapa kementerian, diantaranya yaitu Kementerian Desa Pembangunan Daerah Tertinggal dan Transmigrasi, Kementerian Dalam Negeri, dan Kementerian Keuangan. ${ }^{60}$

Salah satu hasil evaluasi di tahun 2019 adalah adanya temuan beberapa Desa yang kawatir berkurangnya jumlah Dana Desa (DD) yang diterima karena status desanya naik dan keluar dari status desa tertinggal hanya karena tidak mendapatkan Alokasi Afirmasi. Akhirnya ada beberapa desa yang tetap melaporkan status desanya sangat tertinggal atau tertinggal hanya karena untuk mendapatkan alokasi afirmasi sehingga total jumlah Dana Desa (DD) yang diterima menjadi banyak, walaupun sebenarnya dengan melihat fakta dan data di lapangan, desa tersebut sudah naik statusnya menjadi berkembang atau bahkan maju. ${ }^{61}$

Dalam melakukan perhitungan alokasi Dana Desa, Kementerian Keuangan bekerjasama dengan Kementerian Desa, Pembangunan Daerah Tertinggal dan Transigrasi dan Kementerian Dalam Negeri melakukan evaluasi dari perhitungan yang dilakukan di tahun 2019. Hasil evaluasi tersebut salah satunya adalah untuk memberikan rasa keadilan pada Desa yang status Desanya naik menjadi bekembang dan maju, yang kemudian tidak mendapatkan Alokasi Afirmasi, maka Kementerian 
Keuangan melakukan perubahan formulasi perhitungan Dana Desa (DD) dan menambahkan Alokasi Kinerja sebagai bentuk apresiasi bagi desa yang status desanya naik dan memberikan kinerja Pemerintahan Desa yang baik. Dengan adanya Alokasi Kinerja ini diharapkan desa akan mempunyai cita-cita untuk naik status desanya. ${ }^{62}$

\section{Kesimpulan}

Dari pembahasan yang telah dilakukan, maka dapat disimpulkan hal-hal sebagai berikut:

1. Perbedaan pengalokasian Dana Desa pada tahun anggaran 2019 dan 2020 terletak pada perubahan formula yang digunakan untuk pengalokasian Dana Desa dimana pada tahun anggaran 2019 rincian Dana Desa setiap desa dan daerah kabupaten/ kota dialokasikan berdasarkan tiga jenis alokasi saja, yaitu Alokasi Dasar, Alokasi Afirmasi, dan Alokasi Formula sedangkan pada tahun anggaran 2020 pengalokasian tersebut berdasarkan empat jenis alokasi, yaitu Alokasi Dasar, Alokasi Afirmasi, Alokasi Kinerja, dan Alokasi Formula.

2. Perbedaan pengalokasian Dana Desa pada tahun anggaran 2019 dan 2020 juga terletak pada persentase pagu setiap alokasi. Pada tahun anggaran 2019 pagu Alokasi Dasar adalah sebesar $72 \%$ dari anggaran Dana Desa nasional kemudian turun menjadi 69\% dari anggaran Dana Desa nasional pada tahun anggaran 2020. Pada tahun anggaran 2019 pagu Alokasi Afirmasi adalah sebesar 3\% dari anggaran Dana Desa nasional kemudian turun menjadi 1.5\% dari anggaran Dana Desa nasional pada tahun anggaran 2020. Pada tahun anggaran 2019 tidak terdapat pagu Alokasi Kinerja, sedangkan pada tahun anggaran 2020 terdapat Alokasi Kinerja yang besarnya 1.5\% dari anggaran Dana Desa nasional. Pada tahun anggaran 2019 pagu Alokasi Formula adalah sebesar 25\% dari anggaran Dana Desa nasional kemudian naik menjadi 28\% dari anggaran Dana Desa nasional pada tahun anggaran 2020.

3. Faktor-faktor yang menyebabkan perubahan formula pengalokasian Dana Desa pada tahun anggaran 2020 adalah terdapat desa yang tidak menginginkan kenaikan status desa karena akan kehilangan Alokasi Afirmasi, evaluasi dari pemerintah untuk menurunkan persentase Alokasi Dasar agar lebih mencerminkan keadilan dan kondisi desa, evaluasi dari pemerintah untuk menaikkan Alokasi Formula agar lebih mencerminkan kondisi riil desa berdasarkan jumlah penduduk, jumlah penduduk miskin, luas wilayah, dan indeks kesulitan geografis, serta pemberian apresiasi/ reward dari pemerintah berupa pemberian Alokasi Kinerja kepada desa-desa yang memiliki kinerja terbaik.

62 Ibid. 


\section{Daftar Pustaka}

Aljannah, S. 2017. Evaluasi Alokasi Dana Desa (ADD) dalam Menunjang Pembangunan Desa di Kecamatan Tambusai Utara Kabupaten Rokan Hulu (Studi Kasus: Desa Tambusai Utara Tahun 2013-2014). JOM Fekon Vol.4 No.1, 816.

Menteri Keuangan. 2018. Peraturan Menteri Keuangan Republik Indonesia Nomor 193/PMK.07/2018 tentang Pengelolaan Dana Desa. Jakarta.

Menteri Keuangan. 2019. Peraturan Menteri Keuangan Republik Indonesia Nomor 205/PMK.07/2019 tentang Pengelolaan Dana Desa. Jakarta.

Menteri Keuangan. 2020. Peraturan Menteri Keuangan Republik Indonesia Nomor 40/PMK.07/2020 tentang Perubahan atas Peraturan Menteri Keuangan Nomor 205/PMK.07/2019 tentang Pengelolaan Dana Desa.

Pemerintah Indonesia. 2014. Undang-undang Nomor 6 Tahun 2014 tentang Desa. Lembaran RI Tahun 2014 No.7. Jakarta: Sekretariat Negara. 
Reformulasi Pengalokasian Dana Desa .... 